\title{
PENINGKATAN HASIL BELAJAR EKONOMI DENGAN MENGGUNAKAN MODEL PEMBELAJARAN KOOPERATIF TIPE JIGSA W KELAS XI IIS SMA NEGERI 2 PALANGKA RAYA
}

\author{
Oleh \\ Redno Setiawan,* Iin Nurbudiyani** \\ Email: iinnurbudiyani@gmaial.com
}

\begin{abstract}
This study aims to determine the learning activities of students and the results of learning economic economics by using the Jigsaw type cooperative learning model for students. This study is a Classroom Action Research (CAR). The subjects of this study were 34 students of class II-2 IIS-2 SMA SMA Palangka Raya. This data collection technique is observation and testing. Data analysis techniques use Qualitative and Quantitative. The results showed that the learning activities of students belonged to the good category and there was an increase in economic learning outcomes in students using the Jigsaw cooperative learning model in the Pre Test of 34 students who received a score of $\geq 78$ reaching $8.82 \%$ ( 3 students) with an average value of 55 , in the first cycle the results of the Post Test which obtained $\geq 78$ reached $58.82 \%$ (20 students) with an average value of 73.08 and in the second cycle the results of the Post Test were scored $\geq 78$ reached $100 \%$ (34 students) with an average score of 84.71 .
\end{abstract}

(C) Muhammadiyah University Palangkaraya

Keywords: Learning Outcomes, Type Jigsaw Cooperative Learning Model

\begin{abstract}
ABSTRAK
Penelitian ini bertujuan untuk mengetahui aktivitas belajar peserta didik dan hasil belajar ekonomi Ekonomi dengan menggunakan model pembelajaran kooperatif tipe Jigsaw pada peserta didik. Penelitian ini merupakan Penelitian Tindakan Kelas (PTK). Subjek penelitian ini adalah peserta didik kelas XI IIS-2 SMA Negeri 2 Palangka Raya sebanyak 34 orang peserta didik. Teknik pengumpulan data ini adalah observasi dan tes. Teknik analisis data menggunakan Kualitattif dan Kuantitatif. Hasil penelitian menunjukkan bahwa aktivitas belajar peserta didik masuk dalam kategori baik dan ada peningkatan hasil belajar Ekonomi pada peserta didik dengan menggunakan model pembelajaran kooperatif tipe Jigsaw pada tes awal (Pre Test) dari 34 peserta didik yang memperoleh nilai $\geq 78$ mencapai $8,82 \%$ ( 3 peserta didik) dengan nilai rata-rata 55, pada siklus I hasil Post Test yang memperoleh $\geq 78$ mencapai 58,82\% (20 orang peserta didik) dengan nilai rata-rata 73,08 dan pada siklus II hasil Post Test yang memperoleh nilai $\geq 78$ mencapai $100 \%$ (34 peserta didik) dengan nilai rata-rata 84,71.
\end{abstract}

(C)Universitas Muhammadiyah Palangkaraya

Kata Kunci: Hasil Belajar, Model Pembelajaran Kooperatif Tipe Jigsaw

Redno Setiawan* Mahasiswa FKIP UM Palangkaaraya

Iin Nurbudiyani** Dosen Universitas Muhammadiyah Palangkaraya 


\section{PENDAHULUAN}

Pendidikan merupakan kebutuhan mendasar bagi manusia dalam rangka untuk meningkatkan sumber daya manusia. Hal ini sesuai dengan tujuan pendidikan nasional sebagaimana yang tertuang dalam Undang- Undang RI Nomor 20 Tahun 2003 Tentang Sistem Pendidikan Nasional adalah sebagai berikut: Pendidikan nasional berfungsi mengembangkan kemampuan dan membentuk watak serta peradaban bangsa yang bermatabat dalam rangka mencerdaskan kehidupan bangsa, bertujuan untuk berkembangnya potensi peserta didik agar menjadi manusia yang beriman dan bertakwa Kepada Tuhan Yang Maha Esa, berahlak mulia, sehat, berilmu, cakap, kreatif, mandiri dan menjadi warga negara yang demokratis serta bertanggung jawab (Depdiknas, 2005, UU RI No. 20 Tentang Sistem Pendidikan Nasional).

Berdasarkan amanat Undangundang di atas jelaslah bahwa tugas seorang guru tidak hanya menyampaikan ilmu saja tetapi masih banyak yang harus dilakukan guru yaitu mendidik peserta didik agar menjadi manusia yang utuh, dengan demikian dapat dikatakan bahwa tugas guru adalah lebih berat seorang guru dituntut penguasaan berbagai kemampuan sebagai guru yang professional dalam bidangnya. Kemampuan yang dimaksud adalah mulai dari cara mengajar, penguasaan materi, pemilihan berbagai metode mengajar, kemampuan membuat perangkat mengajar, sikap, tauladan dan lain sebagainya. Dalam penyelenggaraan pendidikan disekolah yang melibatkan guru sebagai pendidik dan siswa sebagai peserta didik terjadi interkasi belajar mengajar atau proses pembelajaran. Dalam proses pembelajaran ini, guru dengan sadar merencanakan kegiatan pembelajaran secara sistematis dan berpedoman pada seperangkat aturan dan rencana tentang pendidikan yang disebut sebagai kurikulum. Secara bertahap kurikulum mengalami penyempurnaan yang bertujuan untuk meningkatkan mutu pendidikan yang berorientasi pada kemajuan sistem pendidikan nasional. Namun demikian penyempurnaan kurikulum tersebut tidak diimbangi dengan pelaksanaan kurikulum disekolah-sekolah yang berupa proses pembelajaran.

Menurut Gagne (Ratna Wilis Dahar, 2011:2) belajar dapat didefinisikan sebagai suatu proses di mana suatu organisasi berubah perilakunya sebagai akibat pengalaman, sedangkan menurut Suyono dan Hariyanto (2014:9) belajar adalah suatu aktivitas atau suatu proses untuk memperoleh pengetahuan, meningkatkan keterampilan, memperbaiki perilaku, sikap, dan mengokohkan kepribadian.

Berdasarkan pendapat para ahli di atas dapat disimpulkan bahwa belajar adalah suatu aktivitas atau suatu proses untuk memperoleh pengetahuan, keterampilan, perilaku, sikap, dan kepribadian.

Bedasarkan hasil observasi dan wawancara peneliti dengan guru mata pelajaran ekonomi yang terjadi di SMA 
Negeri 2 Palangka Raya hasil belajar peserta didik khususnya pada mata pelajaran ekonomi pada peserta didik kelas XI IIS-2 SMA Negeri 2 Palangka Raya yang berjumlah 34 orang yang terdiri dari 18 laki-laki dan 16 perempuan, dari jumlah tersebut hanya14 peserta didik atau $41,18 \%$ yang mencapai nilai KKM, sementara20 peserta didik atau $58,82 \%$ yang tidak mencapai nilai KKM. Menurut keterangan guru mata pelajaran ekonomi bahwa KKM untuk materi kebijakan moneter dan kebijakan fiskal yang ditetapkan di SMA Negeri 2 Palangka Raya yaitu 78.

Proses pembelajaran yang diterapkan oleh guru lebih banyak menggunakan metode ceramah sehingga peserta didik kurang serius karena merasa bosan. Keaktifan peserta didik terhadap mata pelajaran ekonomi menurun sehingga peserta didik terlihat pasif pada saat mengikuti proses pembelajaran yang berlangsung.

Berdasarkan permasalahan di atas maka perlu diterapkan model pembelajaran yang dapat meningkatkan hasil belajar melalui pembelajaran yang melibatkan keaktifan peserta didik pada saat proses belajar mengajar kurang baik, sehingga hasil belajar peserta didik menurun atau berada dibawah KKM.

Untuk menangani permasalahan di atas penerapan model pembelajaran Jigsaw merupakan solusinya meningkatkan hasil belajar peserta didik. Menurut Lie, (Rusman, 2014:218) bahwa pembelajaran kooperatif model Jigsaw ini merupakan model belajar kooperatif dengan cara siswa belajar dalam kelompok kecil yang terdiri dari empat sampai enam orang secara heterogen dan siswa bekerja sama saling ketergantungan positif dan bertanggung jawab secara mandiri.

Model pembelajaran kooperatif model Jigsaw adalah sebuah model belajar kooperatif yang menitikberatkan pada kerja kelompok peserta didik dalam bentuk kelompok kecil. Dengan demikian model pembelajaran Jigsaw lebih mengutamakan peran aktif peserta didik, sehingga mampu memahami materi pelajaran yang diberikan serta akan meningkatkan hasil belejar peserta didik. Dengan model pembelajaran peserta didik tidak hanya sebagai pendengar tetapi juga dapat terlibat secara aktif pada saat proses belajar mengajar. Menurut Nurhadi (Ningsih, 2014:24) kelebihan model pembelajaran kooperatif tipe Jigsaw adalah sebagai berikut:

1) Meningkatkan kerjasama untuk mempelajari materi yang ditugaskan.

2) Meningkatkan rasa tanggung jawab peserta didik terhadap pembelajarannya sendiri dan juga pembelajaran orang lain.

3) Guru berperan sebagai pendamping, penolong dan mengarahkan peserta didik dalam mempelajari materi pada kelompok ahli yang bertugas menjelaskan materi kepada rekan-rekannya. 
4) Melatih peserta didik untuk lebih aktif dalam berbicara dan berpendapat.

5) Pemerataan penguasaan materi dapat dicapai dalam waktu yang lebih singkat.

Menurut Johanson dan Jason (Rusman, 2011:219) pembelajaran kooperatif tipe jigsaw memiliki beberapa pengaruh positif, antara lain:

1) Meningkatkan hasil belajar;

2) Meningkatkan daya tinggi;

3) Dapat digunakan untuk mencapai tarap penalaran tingkat tinggi;

4) Mendorong tumbuhnya motivasi interaksi (kesadaran individu);

5) Meningkatkan sikap anak positif terhadap sekolah;

6) Meningkatkan sikap anak positif terhadap guru;

7) Meningkatkan harga diri;

8) Meningkatkan perilaku penyesuaian sosial yang positif; dan

9) Meningkatkan keterampilan hidup bergotong royong.

Selain itu juga akan terjadi interaksi dalam bentuk kooperatif yang dapat memicu terbentuknya ide baru dalam memperkaya perkembangan intelektual peserta didik.

Dapat disimpulkan kelebihan dari pembelajaran Jigsaw yaitu meningkatkan rasa tanggung jawab peserta didik terhadap proses pembelajaran dan meningkatkan hasil belajar.

Berdasarkan permasalahan di atas, maka peneliti tertarik untuk melakukan penelitian dengan judul Peningkatan Hasil Belajar Ekonomi Dengan Menggunakan Model Pembelajaran Kooperatif Tipe Jigsaw Kelas XI IIS SMA Negeri 2 Palangka Raya.

Tujuan yang ingin dicapai dalam penelitian ini adalah:

1. Untuk mendeskripsikan aktivitas belajar peserta didik pada saat pembelajaran Ekonomi dengan menggunakan Model Jigsaw kelas XI IIS-2 SMA Negeri Palangka Raya.

2. Untuk meningkatkan hasil belajar Ekonomi dengan menggunakan Model Jigsaw pada peserta didik kelas XI IIS-2 SMA Negeri 2 Palangka Raya.

\section{METODE PENELITIAN}

Jenis penelitian yang digunakan dalam penelitian ini adalah menggunakan rancangan Penelitian Tindakan Kelas (PTK). Penelitian tindakan kelas dapat mengarahkan para guru untuk melakukan kolaborasi, refleksi, dan bertanya satu dengan yang lain dengan tujuan tidak hanya tentang program dan metode mengajar, tetapi juga membantu para guru mengembangkan hubungan-hubungan personal.

Menurut Asrori (2008:6) penelitian tindakan kelas adalah sebagai suatu bentuk penelitian yang bersifat reflektif dengan melakukan tindakantindakan tertentu untuk memperbaiki dan meningkatkan praktik pembelajaran di kelas secara lebih berkualitas sehingga siswa dapat memperoleh hasil belajar yang lebih baik. 
Sedangkan Menurut Kunandar (2013:45) Penelitian tindakan kelas memiliki tiga unsur atau konsep yaitu:

1. Penelitian adalah aktivitas mencermati suatu objek tertentu melalui metodologi ilmiah dengan mengumpulkan data-data dan dianalisis untuk menyeleseikan suatu masalah.

2. Tindakan adalah suatu aktivitas yang sengaja dilakukan dengan tujuan tertentu yang berbentuk siklus kegiatan dengan tujuan memperbaiki atau meningkatkan mutu atau kualitas proses belajar mengajar.

3. Kelas adalah sekelompok siswa yang dalam waktu yang sama menerima pelajaran yang sama dari seorang guru.

Berdasarkan uraian di atas dapat disimpulkan penelitian tindakan kelas adalah suatu bentuk penelitian yang bersifat reflektif dengan melakukan tindakan-tindakan tertentu untuk memperbaiki dan meningkatkan praktik pembelajaran di kelas.

\section{HASIL DAN PEMBAHASAN}

1. Aktivitas Peserta Didik Pada Saat Menggunakan Model Jigsaw

Adapun hasil observasi terhadap aktivitas peserta didik dalam proses pembelajaran, serta ketuntasan belajar Ekonomi peserta didik adalah adanya peningkatan aktivitas peserta didik dalam proses pembelajaran di kelas dengan menggunakan model pembelajaran kooperatif tipe Jigsaw pada Siklus I dan Siklus II. Hasil pengamatan Siklus I yang dilakukan dua observer memiliki jumlah rata-rata 2,8 dengan kategori cukup tetapi belum mencapai skor yang di tentukan dalam indikator keberhasilan penelitian ini yaitu skor rata-rata minimal 3, maka penelitian ini dianggap belum berhasil dan harus dilanjutkan ke Siklus selanjutnya. Sedangkan hasil pengamatanpada Siklus II meningkat menjadi 3,55 dengan kriteria baik dengan demikian penelitian ini di anggap sudah berhasil di lihat dari hasil data kualitatif karena sudah mencapai indikator keberhasilan yang sudah ditentukan.dan memberikan tanggapan positif berkaitan dengan materi yang akan dipelajari. Ketika pada pembelajaran siklus I masih banyak peserta didik yang belum siap dalam mengikuti pembelajaran dan kurang memberikan tanggapan positif, hal ini ditunjukan dengan sikap peserta didik yang sibuk dengan temannya dan kurang memperhatikan pendidik. Pada siklus II aktivitas peserta didik mengalami peningkatan yang signifikan pada beberapa aspek, misalnya menunjukkan sikap siap untuk mengikuti pembelajaran baik secara fisik maupun mental ketika pendidik 


\begin{abstract}
mengkondisikan kelas dan memberikan tanggapan positif berkaitan dengan materi yang akan dipelajari. Ketika pada pembelajaran siklus I masih banyak peserta didik yang masih belum siap dalam mengikuti pembelajaran dan kurang memberikan tanggapan positif, hal ini ditunjukkan dengan sikap peserta didik yang sibuk dengan temannya dan kurang memperhatikan pendidik. Pada aspek keantusiasan peserta didik dalam mengikuti kegiatan pembelajaran dengan model Jigsaw pada siklus I kurang antusias karena peserta didik masih belum terbiasa dengan model pembelajaran ini sedangkan pada siklus II mengalami peningkatan karena peserta didik mulai terbiasa dengan penggunaan model tersebut.
\end{abstract}

2. Peningkatan Hasil Belajar Ekonomi Setelah Menggunakan Model Jigsaw Pada Materi Kebijakan Moneter dan Kebijakan Fiskal.

Hasil belajar yang diperoleh berdasarkan hasil tes pada peserta didik kelas XI IIS-2 SMA Negeri 2 Palangka Raya yang menggunakan model Jigsaw sebagai model pembelajaran. Pada Siklus I dan Siklus II. Sebelummenggunakan model pembelajaran tipe Jigsaw hanya $8,82 \%$ dan pada Siklus I mengalami peningkatan yang signifikan dengan 58,82\% namun belum memenuhi standar ketuntasan klasikal dengan $85 \%$. Untuk itu penelitian dilanjutkan ke Siklus II dan menghasilkan hasil belajar peserta didik dengan pesentase $100 \%$. Karena telah melebihi standar ketuntasan klasikal, maka penelitian dihentikan pada Siklus II. Dengan demikian model pembelajaran tipe Jigsaw memiliki dampak positif terhadap peningkatan hasil belajar Ekonomi pada peserta didik kelas XI IIS-2 SMA Negeri 2Kota Palangka Raya.

\section{KESIMPULAN}

Dari hasil penelitian dan pembahasan pada siklus I dan siklus II, maka dapat disimpulkan sebagai berikut:

1. Aktivitas belajar peserta didik aktif dengan kategori baik pada saat proses pembelajaran dengan menggunakan model pembelajaran kooperatif tipe Jigsaw kelas XI IIS-2 SMANegeri 2 Palangka Raya. Peserta didik aktif dalam berdiskusi dengan anggota kelompoknya, aktif dalam bertanya jawab baik secara lisan maupun tertulis, dapat fokus pada pembelajaran.

2. Ada peningkatan hasil belajar Ekonomi pada peserta didik dengan menggunakan model pembelajaran kooperatif tipe 


\begin{abstract}
Jigsaw pada tes awal (Pre Test) dari 34 peserta didik yang memperoleh nilai $\geq 78$ mencapai $8,82 \% \quad$ (3 peserta didik) dengan nilai rata-rata 55 , pada siklus I hasil Post Test yang memperoleh $\geq 78$ mencapai $58,82 \%$ (20 orang peserta didik) dengan nilai ratarata 73,08 dan pada siklus II hasil Post Test yang memperoleh nilai $\geq 78$ mencapai $100 \% \quad$ (34 peserta didik) dengan nilai rata-rata 84,71. Hal ini berarti dengan menggunakan model pembelajaran kooperatif tipe Jigsaw dapat meningkatkan hasil belajar peserta didik kelas XI IIS-2 SMA Negeri 2 Palangka Raya.
\end{abstract}

\section{DAFTAR PUSTAKA}

Asrori, Muhammad., (2008). Penelitian Tindakan Kelas. Bandung: Wacana Prima
Depdiknas, (2005), Undang-Undang RI No. 20 Tentang Sistem Pendidikan

Kunandar. (2013). Langkah Mudah Penelitian Tindakan Kelas Sebagai Pengembangan Profesi Guru. Jakarta: Rajawali Pers.

Ningsih Sarie Gusvita. (2014). Upaya Meningkatkan Hasil Belajar IPS Dengan Menggunakan Metode Jigsaw pada SMP GUPPI di Palangka Raya Tahun Pelajaran 2013/2014.Skripsi Universitas Muhammadiyah Palangka Raya: Tidak diterbitkan.

Ratna Wilis Dahar. (2011). TeoriTeori Belajar \& Pembelajaran. Jakarta: Erlangga.

Rusman . (2014). Model-Model PembelajaranMengembangkan Profesionalisme Guru. Jakarta: Rajawali Pers.

Rusman., (2011). Model-Model Pembelajaran Mengembangkan Profesionalisme Guru. Jakarta: Raja Grafindo Persada.

Suyono \&Hariyanto. (2014). Belajar dan Pembelajaran Teori dan Konsep Dasar. Bandung: Remaja Rosdakarya. 